\title{
Article \\ Effect of Bioaugmentation with Anaerobic Fungi Isolated from Ruminants on the Hydrolysis of Corn Silage and Phragmites australis
}

\author{
Bhargavi Ravi ${ }^{1,2}$, Valentine Nkongndem Nkemka ${ }^{2}$, Xiying Hao ${ }^{2}$, Jay Yanke ${ }^{2}$, Tim A. McAllister ${ }^{2}$, Hung Lee ${ }^{3}$, \\ Chitraichamy Veluchamy ${ }^{1}(\mathbb{D})$ and Brandon H. Gilroyed ${ }^{1, *(\mathbb{D})}$ \\ 1 School of Environmental Sciences, University of Guelph Ridgetown Campus, Ridgetown, ON NOP 2C0, \\ Canada; bhargaviravi20@gmail.com (B.R.); chitraiv@uoguelph.ca (C.V.) \\ 2 Agriculture and Agri-Food Canada, Lethbridge Research Station, Lethbridge, AB T1J 4P4, Canada; \\ vallynkemka@gmail.com (V.N.N.); xiying.hao@canada.ca (X.H.); jay.yanke@canada.ca (J.Y.); \\ tim.mcallister@canada.ca (T.A.M.) \\ 3 School of Environmental Sciences, University of Guelph, Guelph, ON N1G 2W1, Canada; hlee@uoguelph.ca \\ * Correspondence: bgilroye@uoguelph.ca; Tel.: +1-519-674-1500 (ext. 63605)
}

\section{check for}

updates

Citation: Ravi, B.; Nkongndem Nkemka, V.; Hao, X.; Yanke, J.; McAllister, T.A.; Lee, H.; Veluchamy, C.; Gilroyed, B.H. Effect of

Bioaugmentation with Anaerobic Fungi Isolated from Ruminants on the Hydrolysis of Corn Silage and Phragmites australis. Appl. Sci. 2021, 11,9123. https://doi.org/10.3390/ app11199123

Academic Editor: Ramaraj Boopathy

Received: 9 August 2021

Accepted: 24 September 2021

Published: 30 September 2021

Publisher's Note: MDPI stays neutral with regard to jurisdictional claims in published maps and institutional affiliations.

Copyright: (c) 2021 by the authors. Licensee MDPI, Basel, Switzerland. This article is an open access article distributed under the terms and conditions of the Creative Commons Attribution (CC BY) license (https:/ / creativecommons.org/licenses/by/ $4.0 /)$.
Abstract: Anaerobic fungi produce extracellular hydrolytic enzymes that facilitate degradation of cellulose and hemicellulose in ruminants. The purpose of this work was to study the impact of three different anaerobic fungal species (Anaeromyces mucronatus YE505, Neocallimastix frontalis 27, and Piromyces rhizinflatus YM600) on hydrolysis of two different lignocellulosic substrates, corn (Zea mays L.) silage and reed (Phragmites australis (Cav.) Trin. ex Steud.). Biomass from each plant species was incubated anaerobically for 11 days either in the presence of live fungal inoculum or with heatinactivated (control) inoculum. Headspace gas composition, dry matter loss, soluble chemical oxygen demand, concentration of volatile fatty acids, and chemical composition were measured before and after hydrolysis. While some microbial activity was observed, inoculation with anaerobic fungi did not result in any significant difference in the degradation of either type of plant biomass tested, likely due to low fungal activity or survival under the experimental conditions tested. While the premise of utilizing the unique biological activities of anaerobic fungi for biotechnology applications remains promising, further research on optimizing culturing and process conditions is necessary.

Keywords: Anaeromyces mucronatus; lignocellulose; Neocallimastix frontalis; Piromyces rhizinflatus; pretreatment; hydrogen; biomass

\section{Introduction}

In Europe, more than 13,638 biogas plants (72\%) utilize the agricultural feedstocks out of 18,943 biogas plants [1], among which corn (Zea mays L.) silage is the major feedstock [2]. While corn silage is the most widely used energy crop for biogas production, there is interest in using other sources of plant biomass for environmental, economic, and societal reasons [3]. For example, Phragmites australis (Cav.) Trin. ex Steud. (common reed) is a perennial invasive wetland plant species in North America that produces substantial quantities of biomass of up to $30 \mathrm{t} \mathrm{ha}^{-1} \mathrm{y}^{-1}$ [4]. While all parts of the common reed can be used for both biogas and biofuel production [5], the estimated biogas yields reported in the literature are only $150 \mathrm{~L} \mathrm{~kg}^{-1}$ volatile solids (VS) of fresh material compared to grass and pig manure that yield more than 280 and $340 \mathrm{~L} \mathrm{~kg}^{-1} \mathrm{VS}$, respectively [4,6]. The issues of low degradability and poor conversion to biogas are also applicable to other potential energy crops, such as Miscanthus and Arundo donax L. [7,8].

In nature, one of the most efficient systems for unlocking the energy found in lignocellulosic substrates is the rumen animals such as cattle and sheep. While the stepwise fermentation process (hydrolysis, acidification, acetogenesis, methanogenesis) that occurs during anaerobic digestion (AD) is crudely similar to the digestive process in the rumen, it 
is far less efficient [9]. One reason for the reduced efficiency of AD compared to the rumen likely lies in differences in the microbial populations between these two environments. The anaerobic digestive system of the rumen has been extensively studied, and anaerobic fungi (AF) are known to be involved in the digestion of the most recalcitrant lignocellulose within the rumen [10]. Anaerobic fungi use rhizoids to physically penetrate and disrupt the lignin layer of lignocellulose, while also enzymatically degrading plant cell walls using a diverse suite of extracellular hydrolytic enzymes, including cellulases, hemicellulases, pectinases, and phenolic acid esterases [11]. Some of the extracellular hydrolytic enzymes produced by these organisms are freely released into the milieu; others are bound to the cellular surface as components of multienzyme cellulosomes [12]. Using feruloyl esterase activity, AF cleaves the bonds between hemicellulose and lignin, increasing the access of microbial enzyme to hemicelluloses. Although AF are known to degrade lignin, they do not utilize the lignin themselves [13]. While AF are known to play an essential role within the rumen, their presence, abundance, and activity level in AD is not well understood.

Bioaugmentation involves adding specific microorganisms into a system or process in order to improve its efficiency [14]. Several studies have been conducted using bioaugmentation with bacteria or fungi as a pretreatment for the hydrolysis of lignocellulosic substrates prior to AD [12]. In one study, the addition of thermophilic Geobacillus sp. strain AT1 to a biogas reactor using sewage sludge as substrate resulted in a $210 \%$ increase in biogas production due to the protease activity of the microbe [15]. In another study, 22 isolates of white rot fungi were used individually to pretreat wheat straw, with the greatest lignin degradation and subsequent increase in biogas yield (from $0.293 \mathrm{~L} \mathrm{~g}^{-1}$ to $0.343 \mathrm{~L} \mathrm{~g}^{-1}$ ) obtained from an isolate of Pleurotus florida [16].

Recently, studies utilizing AF to improve biogas production and speed up substrate degradation have been reported [17-19]. To date, isolates of the genera Anaeromyces, Neocallimastix, and Piromyces have been added to AD systems in an effort to improve lignocellulose degradation and ultimately improve methane yield [18,19]. A previous study [18] demonstrated increased biogas yields from different substrates, such as maize silage, anaerobic sludge, and microcrystalline cellulose, with bioaugmentation of AF in fed batch semicontinuous digesters. In that study, addition of $8 \mathrm{mg}$ dry mycelium of Anaeromyces sp. (strains KF8 or JF1) or mixed cultures of $1.9 \mathrm{mg}$ dry mycelium of Anaeromyces sp. KF8 and Piromyces sp. KF9 increased biogas yield by up to $22 \%$. Although the study demonstrated an increase in biogas yield with $\mathrm{AF}$, the researchers did not determine if the increase in biogas occurred as a result of the addition of AF or the anaerobic microbes that were already present in the sludge. Another study [18] explored bioaugmentation of a two-stage reactor with Piromyces rhizinflata, using corn silage and cattail as substrates, which resulted in an initial increase of $\mathrm{H}_{2}$ and $\mathrm{CH}_{4}$ production but with no overall increase in biogas production. They proposed that this response occurred as a result of rapid wash out of AF from the anaerobic digester systems. There may also have been additional challenges with integration of AF into the microbial populations within the AD. A recent study [20] surveyed 10 agricultural biogas plants for the presence and transcriptional activity of $\mathrm{AF}$, concluding that survival and activity were impeded by the process conditions prevalent in commercial scale biogas systems.

Based on the seeming lack of activity from AF in commercial biogas systems [20] and poor survival of AF bioaugmented into lab-scale AD systems [18], this study was designed to evaluate the efficacy of AF as a hydrolytic pretreatment for lignocellulosic biomass. We evaluated the effect of three different fungal species (Anaeromyces mucronatus YE505, Neocallimastix frontalis 27, and Piromyces rhizinflatus YM600), which were previously isolated from ruminants and known to possess hydrolytic activity against lignocellulosic substrates, on microbial hydrolysis of corn silage and common reed. 


\section{Materials and Methods}

\subsection{Feedstock}

Corn silage (Zea mays L.) and common reed (Phragmites australis (Cav.) Trin. ex Steud.) were used as substrates for fungal hydrolysis. Corn silage was obtained from a commercial beef cattle feedlot in Lethbridge County, Alberta, Canada. Common reed, harvested in July, was obtained from Ridgetown, ON, Canada.

\subsection{Anaerobic Fungal Strains, Media, and Culturing Conditions}

Pure cultures of three AF were obtained from the microbial collection lab at the Agriculture and Agri-Food Canada Lethbridge Research and Development Centre: Anaeromyces mucronatus YE505 (elk isolate), Neocallimastix frontalis 27 (cow isolate), and Piromyces rhizinflatus YM600 (moose isolate). Inocula of the fungal cultures were maintained anaerobically at $39^{\circ} \mathrm{C}$ in modified semi-defined Lowe's medium B [21] with barley straw (ground $<1 \mathrm{~mm}$ ) as the sole carbon source. The ground barley comprised $5 \%$ of the mass $(0.05 \mathrm{~g})$ of the anaerobic media (about $5 \mathrm{~mL}$ ) in the test tube and was then autoclaved for $20 \mathrm{~min}$ at $120{ }^{\circ} \mathrm{C}$ with $103.4 \mathrm{kPa}$ pressure. After autoclaving, the media was cooled down and fungal cultivation was carried out using the Hungate technique [22]; tubes were inoculated by transferring fungal biomass from already existing culture tubes using a Pasteur pipet under anaerobic conditions. After inoculation, tubes were incubated at $39{ }^{\circ} \mathrm{C}$ in an incubator for 4 days to allow for fungal growth, and then the AF with spent medium was transferred to Erlenmeyer flasks at the start of the hydrolysis experiment.

\subsection{Hydrolysis Experiment}

Hydrolysis of plant biomass was evaluated in $0.5 \mathrm{~L}$ Erlenmeyer flasks. The total solids (TS) content of all flasks was set at 7.9\% (w/w). A single lot of anaerobic sludge was obtained from a commercial scale biogas facility (Lethbridge Biogas LP) that co-digests livestock manures with industrial food processing waste. Anaerobic sludge was autoclaved for $20 \mathrm{~min}$ at $120{ }^{\circ} \mathrm{C}$ with $103.4 \mathrm{kPa}$ pressure to inactivate background microbial activity and then used as a buffering solution in each flask. Triplicate samples of autoclaved sludge were analyzed and used to determine the chemical and physical properties. The sludge had a $\mathrm{pH}$ of 7.88 , total bicarbonate alkalinity of $16.66 \mathrm{~g} \mathrm{~L}^{-1}$ and TS of $1.66 \%$.

A total of 36 flasks were used for this hydrolysis experiment. Flasks containing either corn silage or common reed were individually inoculated with each of the three AF in triplicate. Each corn silage flask contained $200 \mathrm{~mL}$ of anaerobic sludge, $80 \mathrm{~mL}$ fungal inoculum (comprising 20\% of the total working volume), $92.8 \mathrm{~g}$ of corn silage, and $100 \mathrm{~mL}$ of distilled water. Each common reed flask contained $200 \mathrm{~mL}$ of anaerobic sludge, $80 \mathrm{~mL}$ fungal inoculum, $57.6 \mathrm{~g}$ common reed, and $140 \mathrm{~mL}$ of distilled water. Control flasks were also set up in triplicate in a manner identical to those described above, except that the fungal inocula were first killed by autoclaving prior to addition to the flasks. Inoculated flasks were then flushed with nitrogen for 1-2 min to ensure anaerobic conditions and sealed with butyl rubber stoppers connected to aluminum gas tight bags (Multilayer Transofoil, Flextrus AD, Sweden) as described in [23]. Flasks were equipped with sampling ports for gas and liquid sample extraction. The experiment was conducted under mesophilic conditions $\left(40 \pm 1^{\circ} \mathrm{C}\right)$ by placing flasks in a water bath (2870; Thermo Fisher Scientific, Waltham, MA, USA) and manually agitated at least three times a day.

\subsection{Analytical Methods}

\subsubsection{Gas Analysis}

Gas samples $(10 \mathrm{~mL})$ were taken daily from the headspace of each flask and transferred to $5.9 \mathrm{~mL}$ evacuated glass vials (Exetainer; Labco Limited, Lampeter, UK) prior to analysis using gas chromatography (GC). Gas samples were analyzed for $\mathrm{CO}_{2}$ and $\mathrm{CH}_{4}$ concentrations using a two-channel micro-GC (Varian 4900, Palo Alto, CA, USA) equipped with a thermal conductivity detector [24]. Operational parameters of the GC were as follows: channel $\mathrm{A}\left(\mathrm{H}_{2}\right.$ analysis) injector $110^{\circ} \mathrm{C}$, column oven $40^{\circ} \mathrm{C}$, argon carrier gas at 
$150 \mathrm{kPa}$; channel $\mathrm{B}\left(\mathrm{CH}_{4}, \mathrm{CO}_{2}\right.$ analysis $)$ injector $80^{\circ} \mathrm{C}$, column oven $40^{\circ} \mathrm{C}$, helium carrier gas at $100 \mathrm{kPa}$. Total gas volume from each flask was captured in individual gas-tight bags and quantified using a $0.1 \mathrm{~L}$ glass syringe (Perfektum ${ }^{\mathrm{TM}}$ Jumbo Glass Syringes, Cadence Science $^{\mathrm{TM}}$, Cranston, RI, USA). Gas volumes reported were normalized to $0{ }^{\circ} \mathrm{C}$ and $1 \mathrm{~atm}$.

\subsubsection{Liquid Analysis}

Liquid samples were extracted from a sampling port on each flask every $48 \mathrm{~h}$ using a $10 \mathrm{~mL}$ syringe and divided into aliquots for further analysis as described below. The TS and VS of liquid samples were measured following a standard protocol [25]. To estimate the extent of lignocellulose hydrolysis and the amount of remaining dissolved organic matter, soluble chemical oxygen demand (COD) was determined according to the manufacturer's protocol (Dr. Lange test kit HR mercury free, 20-1500 $\mathrm{mg} \mathrm{L}^{-1}$, Mississauga, ON, Canada). Samples used for COD analysis were first syringe filtered through $0.45 \mu \mathrm{m}$ nylon filter (Chromatographic Specialties Inc., Brockville, ON, Canada) and then digested using a digital reactor block (HACH DRB200, Loveland, CO, USA) at $150{ }^{\circ} \mathrm{C}$ for $2 \mathrm{~h}$. After digestion, absorbance of the sample was measured using a spectrophotometer (DR900, HACH, Mississauga, ON, Canada).

The $\mathrm{pH}$ and total bicarbonate alkalinity were measured using a BIOGAS titration Manager (R41T114, HACH, Vésenaz, Switzerland). Liquid samples were also analyzed for volatile fatty acids (VFA; acetate acid, n-butyrate, iso-butyrate, propionate, n-valerate, iso-valerate, and caproate) by GC (Agilent 6890 N, Agilent, Mississauga, ON, Canada). The samples were prepared by first filtering using $0.45 \mu$ m nylon filter (Chromatographic Specialties Inc., Brockville, ON, Canada), then $25 \%$ meta phosphoric acid was added to the filtered sample in the ratio of 5:1 sample to acid. The gas chromatograph was equipped with a flame ionization detector maintained at $250{ }^{\circ} \mathrm{C}$, and a fused silica capillary column (ZB-FFAP, $30 \mathrm{~m} \times 0.32 \mathrm{~mm} \times 1.0 \mu \mathrm{m}$ : Phenomenex, Torrance, LA, USA). The equipment was set at split mode and the split injection ratio was 5:1. Helium was used as the carrier gas and the analytical steps were performed according to the procedures outlined in Gilroyed et al. [26].

Concentration of soluble ions $\left(\mathrm{NH}_{4}{ }^{+}, \mathrm{Na}^{+}, \mathrm{K}^{+}, \mathrm{Ca}^{2+}, \mathrm{Mg}^{2+}\right)$ were determined after filtration through $0.45 \mu \mathrm{m}$ filter paper using ion chromatography (ICS-1000 and DX-600, Dionex, Sunnyvale, CA, USA). The concentration of free (unionized) $\mathrm{NH}_{3}$ was calculated as previously reported [27]. To determine the ratio of total carbon to total nitrogen in samples, a subsample ( $5 \mathrm{mg}$ ) was freeze dried for 1 week and ground to a size $<0.15 \mathrm{~mm}$ using a Cyclone sample mill (UDY Corporation, Fort Collins, CO, USA), and then analyzed using a CNS analyzer (NA-1500, Carlo Erba, Rodano, Italy) linked via a continuous flow interface to an Optima isotope ratio mass spectrometer (Micromass, Manchester, UK).

\subsubsection{Fiber Analysis and C:N}

Fiber analysis was performed to characterize the composition (cellulose, hemicellulose, and lignin content) of corn silage and common reed before hydrolysis. Before taking samples for analysis, corn silage and common reed were thoroughly mixed in the containers that they stored to obtain a uniform and unbiased sample for analysis. Triplicate samples of each feedstock were air dried for 1 week and then ground through a screen of $1 \mathrm{~mm}$ mesh size in a tabletop mill grinder (Wiley mill standard model 4; Arthur H. Thomas Co., Philadelphia, PA, USA). The contents of lignin, hemicellulose, and cellulose were analyzed according to a modified method of [28] with thermal stable amylase (Termamyl ${ }^{\circledR}$ 120, Sigma-Aldrich Co. LLC., St. Louis, MO, USA) and sodium sulfite (S430-3 sodium sulfite anhydrous, Fisher Scientific Int., Inc., Pittsburgh, PA, USA) included in the NDF procedure [29]. Total carbon and total nitrogen concentrations were determined from freeze-dried, finely ground samples using a Model 1500 Nitrogen/Carbon analyzer (Carlo Erba Instruments, Milan, Italy). 


\subsection{Statistical Analysis}

One-way ANOVA and repeated measures ANOVA tests were performed for statistical analysis using IBM SPSS version 24.0. The different treatments (Anaeromyces mucronatus YE505, Neocallimastix frontalis 27, and Piromyces rhizinflatus YM600) were kept as independent variables, and the different analytical tests, such as average cumulative hydrogen and $\mathrm{CO}_{2}$ gas production, and changes in $\mathrm{COD}, \mathrm{pH}$, and VFA, were considered as dependent variables.

\section{Results and Discussion}

\subsection{Feedstock Characteristics}

The TS of corn silage and common reed were $33.5 \% \pm 0.6$ and $54.7 \% \pm 0.8$, of which $96.3 \% \pm 0.6$ and $94.9 \% \pm 0.4$ were VS, respectively (Table 1). The C: $\mathrm{N}$ ratio of corn silage and common reed was $31.2 \% \pm 0.1$ and $26.3 \% \pm 0.7$, respectively; both values were almost within the optimum range of 20 to 30 for $\mathrm{AD}$ [30]. In terms of fiber composition, corn silage had about two times lower $(p<0.05)$ concentrations of cellulose, hemicellulose, and lignin than common reed (Table 1$)$.

Table 1. The physicochemical characteristics of corn silage and common reed.

\begin{tabular}{ccc}
\hline Parameters & Corn Silage & Common Reed \\
\hline TS $^{1}(\%)$ & $33.5 \pm 0.6$ & $54.7 \pm 0.8$ \\
VS $^{2}(\%$ TS) & $96.3 \pm 0.6$ & $94.9 \pm 0.4$ \\
VS added (g) & 30 & 30 \\
Moisture content (\%) & $66 \pm 0.6$ & $44.3 \pm 0.8$ \\
Total carbon: Total nitrogen ratio & $31.2 \pm 0.1$ & $26.3 \pm 0.7$ \\
Hemicellulose (\% of TS) & $12 \pm 4.3$ & $28.7 \pm 0.4$ \\
Cellulose (\% of TS) & $17.2 \pm 1.8$ & $38.7 \pm 0.4$ \\
ADL $^{3}(\%$ TS) & $2.7 \pm 0.0$ & $7.9 \pm 0.3$ \\
\hline
\end{tabular}

${ }^{1}$ Total solids. ${ }^{2}$ Volatile solid. ${ }^{3}$ Acid detergent lignin.

\subsection{Gas Production and Composition}

Cumulative methane production was $<1 \mathrm{~mL} \mathrm{~g}^{-1} \mathrm{VS}$ in all treatments for both corn silage and common reed substrates. Since only hydrolysis was conducted in this study, minimal methane volume was expected. Anaerobic fungi are known to produce $\mathrm{H}_{2}$ and $\mathrm{CO}_{2}$ during substrate hydrolysis [31]. Nkemka and Gilroyed [18] demonstrated that bioaugmentation with anaerobic AF into a two-stage $\mathrm{AD}$ can increase $\mathrm{H}_{2}$ production within the system in the days following inoculation. In our study, an initial increase in hydrogen (Figure 1) and $\mathrm{CO}_{2}$ (Figure 2) production were observed with all fungal species that were added to digesters containing corn silage. Over the course of the 11-day hydrolysis experiment, all three fungal treatments produced similar cumulative volumes of $\mathrm{H}_{2}$, in the range of $46-60 \mathrm{~mL} \mathrm{~g}^{-1} \mathrm{VS}(p>0.05)$ (Figure 1a). Similar trends were observed for $\mathrm{CO}_{2}$ gas production, with cumulative $\mathrm{CO}_{2}$ production for all three treatments of corn silage in the range of $78-93 \mathrm{~mL} \mathrm{~g}^{-1} \mathrm{VS}(p>0.05)$ (Figure 2a). The initial increase in gas production observed for corn silage may have been due to the fact that the material had already undergone ensiling. Additionally, background microbes such as $\mathrm{H}_{2}$-producing Clostridia are known to be present in corn silage and were likely actively contributing to the gas production observed [32]. 

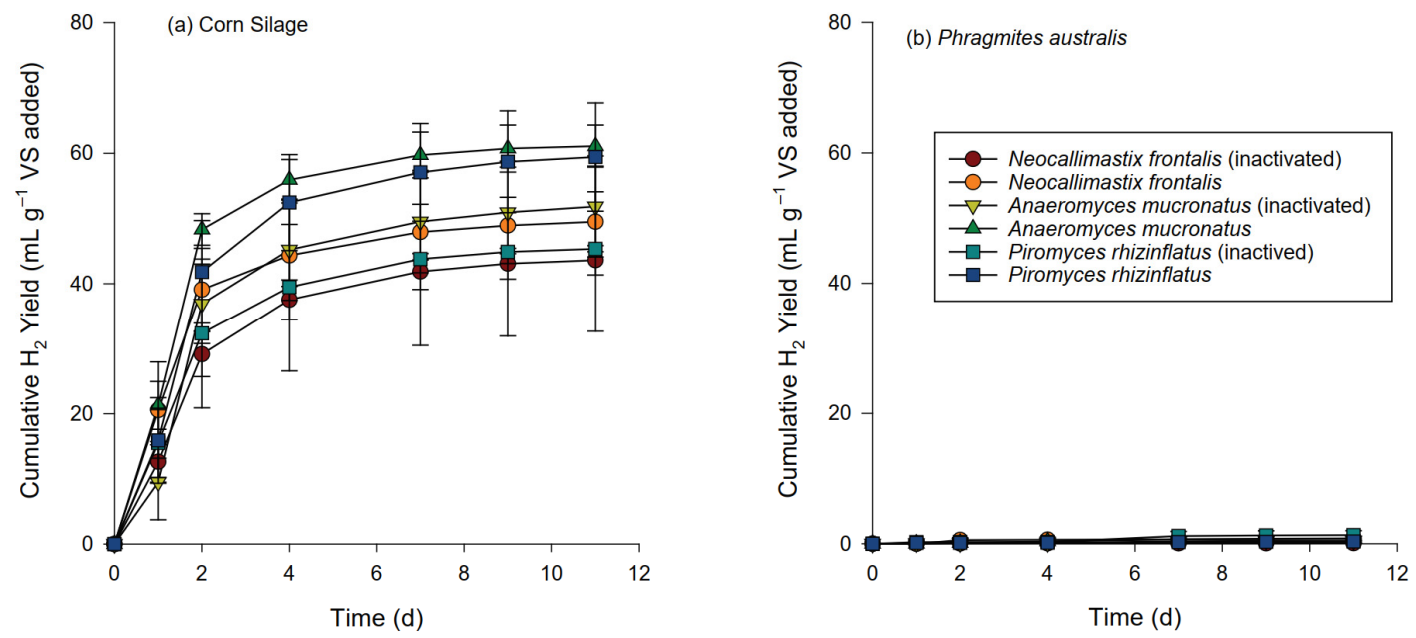

Figure 1. Cumulative hydrogen yield in the bioaugmentation of three different anaerobic fungal species: (a) corn silage (Zea mays L.); (b) common reed (Phragmites australis). Error bars show standard deviation.
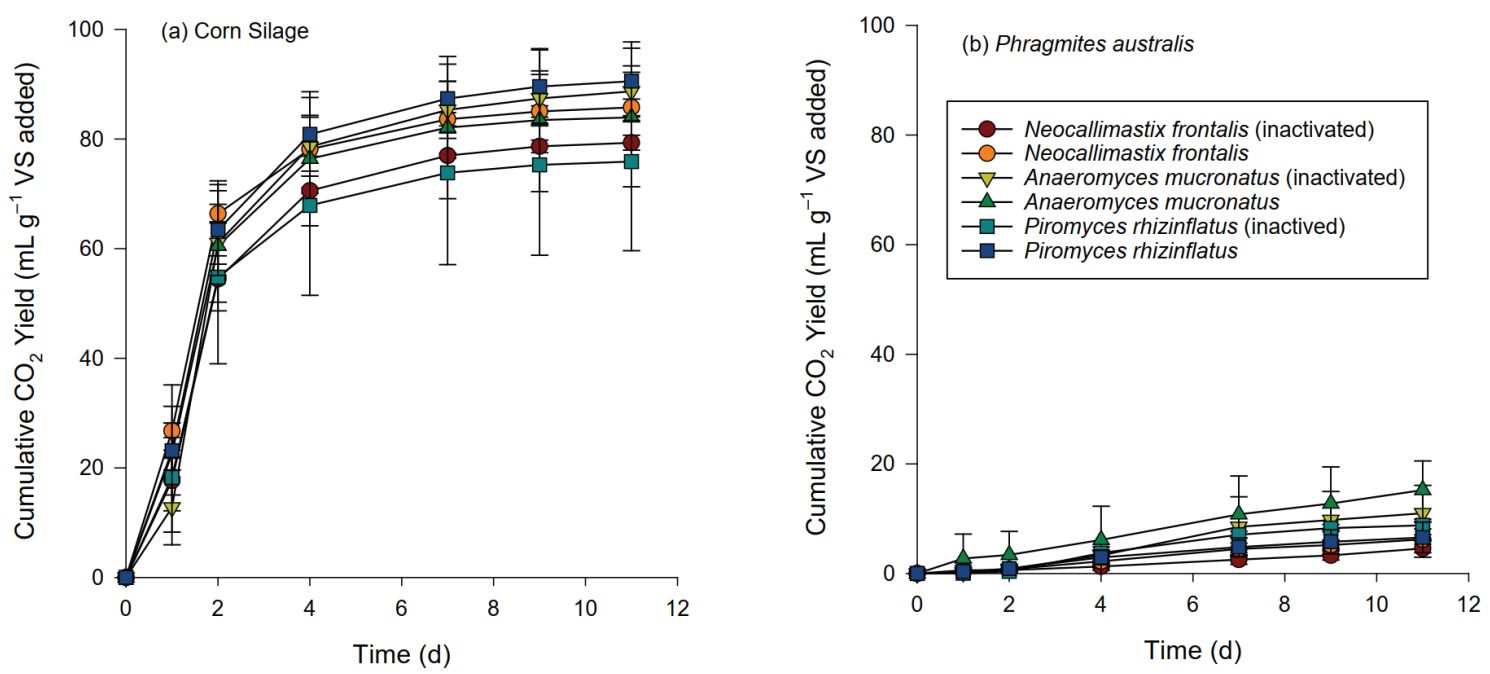

Figure 2. Cumulative carbon dioxide yield in the bioaugmentation of three different anaerobic fungal species: (a) corn silage (Zea mays L.); (b) common reed (Phragmites australis). Error bars show standard deviation.

During hydrolysis of common reed, smaller volumes of $\mathrm{H}_{2}\left(<1 \mathrm{~mL} \mathrm{~g}^{-1} \mathrm{VS}\right)$ (Figure $\left.1 \mathrm{~b}\right)$ and $\mathrm{CO}_{2}\left(<15.5 \mathrm{~mL} \mathrm{~g}^{-1} \mathrm{VS}\right)$ (Figure 2b) gas were evolved from all three treatments than was observed with corn silage $(p>0.05)$. Further studies are required to either eliminate the contribution of background microflora present on the substrate, or to account for the magnitude of their activity within the overall microbial consortia present during substrate hydrolysis.

\subsection{Chemical Changes during Hydrolysis}

Chemical oxygen demand was measured over the course of the hydrolysis experiment to examine the amount of soluble COD released due to hydrolysis and for further AD (Figure 3). Soluble COD concentrations for corn silage treatments trended upwards over time but did not significantly differ pre- and post-hydrolysis (Figure 3a). Similarly, soluble COD concentration did not increase in common reed (Figure $3 b$ ), regardless of treatment $(p>0.05)$, and was approximately half the value compared to corn silage. The higher initial COD concentration in corn silage compared to common reed was likely due to conversion of some corn biomass to soluble fermentation products during the ensiling process. 

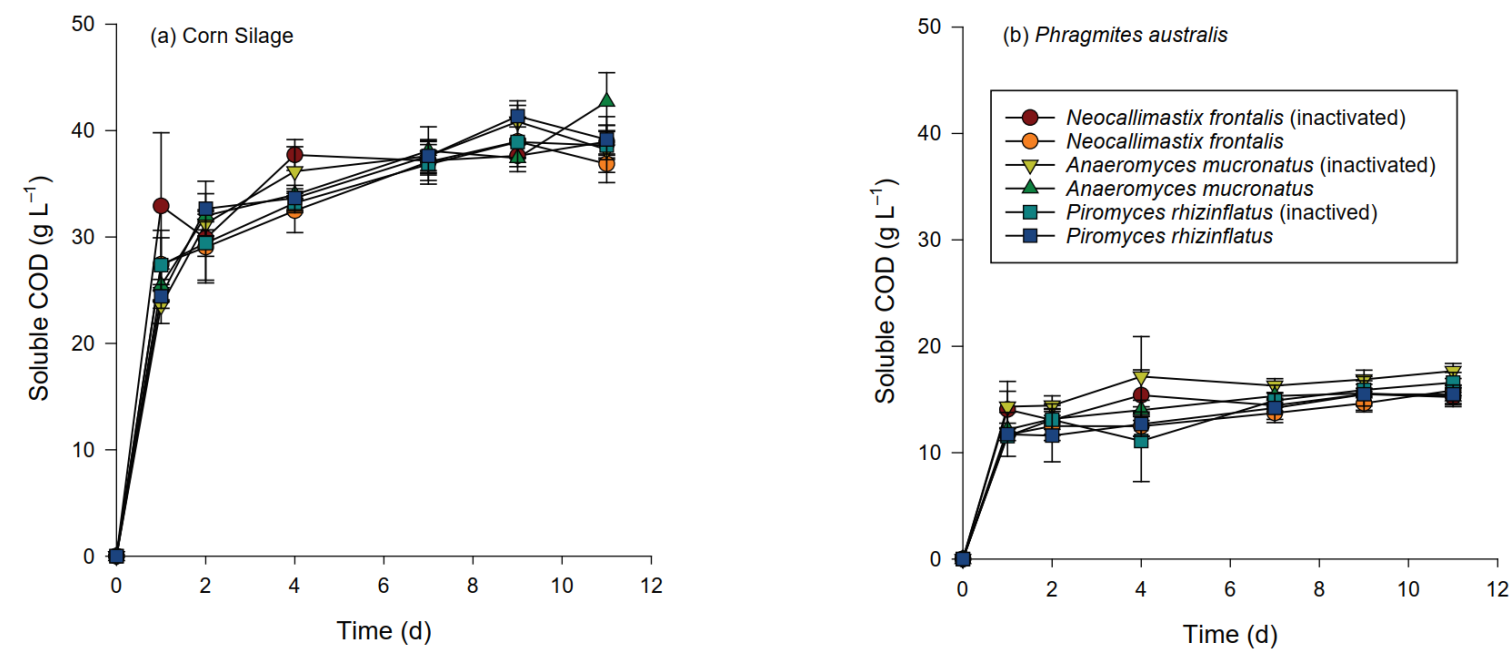

Figure 3. Soluble COD production in the bioaugmentation of three different anaerobic fungal species: (a) corn silage (Zea mays L.); (b) common reed (Phragmites australis). Error bars show standard deviation.

The main VFA produced during hydrolysis of corn silage were acetic, propionic, and butyric acids. Total VFA concentration trended upward over the course of the hydrolysis experiment for corn silage in all treatments; however, these increases were not statistically significant (Figure 4). In comparison, VFA production during hydrolysis of common reed was limited, with no significant difference in concentration observed over the course of the experiment for any treatments. It is unlikely that the lack of VFA accumulation could have been attributed to microbial conversion, as minimal gas volume was produced, suggesting an overall lack of microbial activity. The absence of a functional methanogenic phase in the experimental system could have been inhibitory. The inhibitory concentration of VFA for the specific fungal species investigated here is unknown, but it is possible that the concentrations observed were detrimental to continued fungal growth.
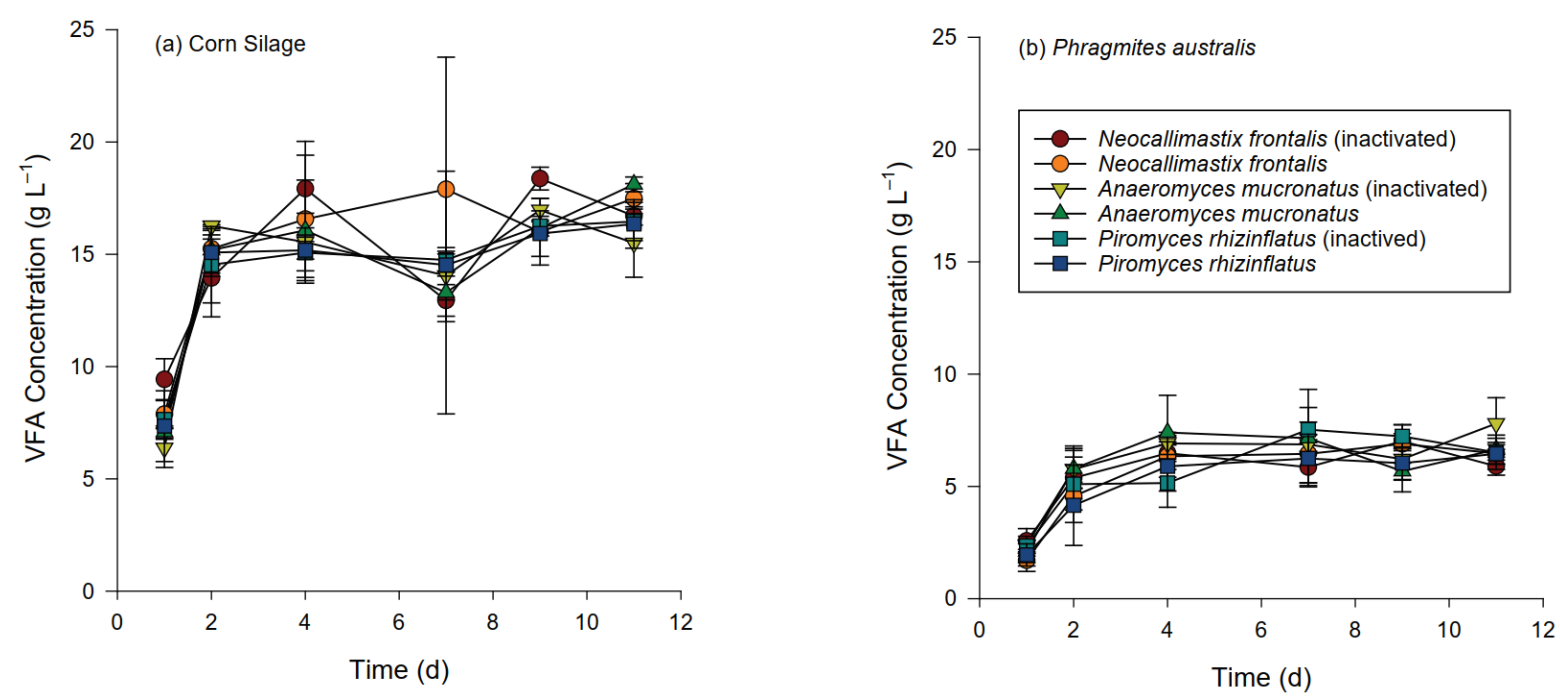

Figure 4. Volatile fatty acids (VFA) production in the bioaugmentation of three different anaerobic fungal species with and without activation: (a) corn silage (Zea mays L.); (b) common reed (Phragmites australis). Error bars show standard deviation.

The $\mathrm{pH}$ of the digestate in corn silage flasks decreased from approximately 7.0 on day 1 to 5.6-5.8 on day 11 for all treatments (Figure $5 \mathrm{a}$ ). The $\mathrm{pH}$ of digestate in common reed flasks ranged between 7.2-8.0 on day 1 (Figure 5 b), which was not statistically different from corn silage $(p>0.05)$. At the end of hydrolysis, the $\mathrm{pH}$ values of common reed decreased to 6.1-6.9, which again was not statistically different from corn silage $(p>0.05)$. 
The optimum $\mathrm{pH}$ range for the growth of $\mathrm{AF}$ is between 6.0 and 7.0 [33], so reduction of $\mathrm{pH}$ to $<6.5$ due to VFA accumulation may have contributed to conditions unfavorable for anaerobic fungal activity. In the rumen, there is both a constant supply of buffering capacity as well as organic acid removal through the production of saliva and the symbiotic activities of the host animal and microbial consortium, respectively. The complexity of the rumen system is difficult to mimic in vitro in the laboratory, but a better approximation of the conditions which are favorable for AF to survive and be active will be essential for future success in this area of research.
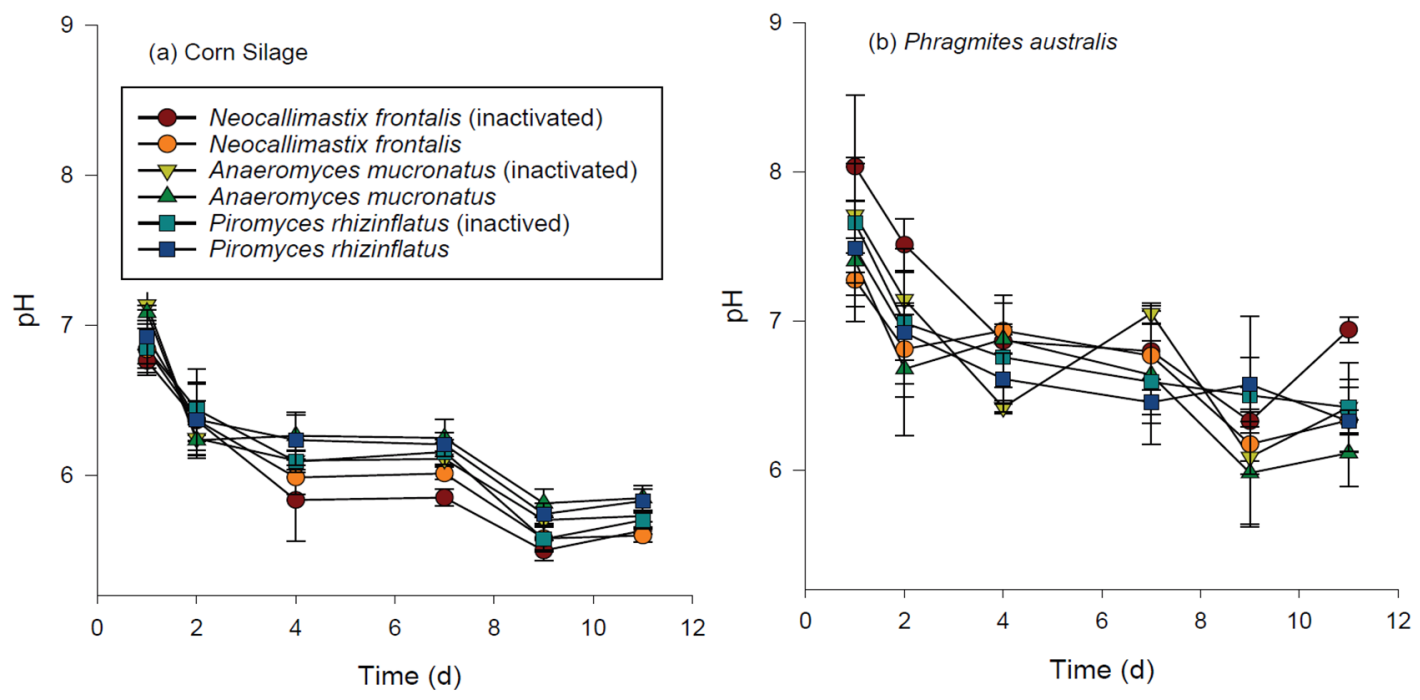

Figure 5. Changes in $\mathrm{pH}$ in the bioaugmentation of three different anaerobic fungal species with and without activation: (a) corn silage (Zea mays L.); (b) common reed (Phragmites australis). Error bars show standard deviation.

Ammonia is known to inhibit hydrolysis during AD at $>200 \mathrm{mg} \mathrm{L}^{-1}$ [34], but that threshold was not exceeded in our study (Table 2). Similarly, metals can inhibit biological hydrolysis processes when present in sufficient concentration. Alkaline metals, such as $\mathrm{Na}^{+}$, $\mathrm{Mg}^{2+}, \mathrm{K}^{+}$, and $\mathrm{Ca}^{2+}$, up to a range of $400 \mathrm{mg} \mathrm{L}^{-1}$ help maintain alkalinity and $\mathrm{pH}$ in $\mathrm{AD}$. However, higher concentrations would cause toxicity and inhibit AD processes [34]. In our study, $\mathrm{Na}^{+}$and $\mathrm{Mg}^{2+}$ concentrations were very low $\left(<1 \mathrm{mg} \mathrm{L}^{-1}\right)$ in all treatments and well below reported inhibitory levels, i.e., $<750 \mathrm{mg} \mathrm{L}^{-1}$ for $\mathrm{Mg}^{2+}$ [35] and 3500-5500 $\mathrm{mg} \mathrm{L}^{-1}$ for $\mathrm{Na}^{+}$[36]. Concentration of $\mathrm{K}^{+}$was $1-3 \mathrm{mg} \mathrm{L}^{-1}$ for all treatments, again below the inhibitory concentration of $400 \mathrm{mg} \mathrm{L}^{-1}$ [34]. Similarly, for $\mathrm{Ca}^{2+}$ the values were $<1 \mathrm{mg} \mathrm{L}^{-1}$ for all treatments and below inhibitory concentrations $\left(>7000 \mathrm{mg} \mathrm{L}^{-1}\right)$. Based on this, the low degree of hydrolysis observed in all treatments was not likely caused by inhibition from ammonia or metals.

When considering our overall results, we can conclude (1) that there was limited hydrolytic activity in any of the reactors, regardless of fungal species or substrate type, and (2) the activity that was present was likely due to background microflora, including the bacteria that are present on the feedstock and not the AF. The most likely explanation for these results is that the AF were unable to survive, or at least be active, in the environment provided in this study. Low activity and survival of anaerobic fungi when applied to non-rumen environments has been reported by others $[17,18,20]$. 
Table 2. Effect of ammonia and alkaline metals in the bioagumentation of three different anaerobic fungal species.

\begin{tabular}{|c|c|c|c|c|c|c|c|}
\hline Substrate & Fungal Species & Active/Inactivated & $\begin{array}{c}\mathrm{NH}_{3} \\
\mathrm{mg} \mathrm{L}^{-1}\end{array}$ & $\begin{array}{c}\mathrm{Na}^{+} \\
\mathrm{mg} \mathrm{L}^{-1}\end{array}$ & $\begin{array}{c}\mathrm{K}^{+} \\
\mathrm{mg} \mathrm{L}^{-1}\end{array}$ & $\begin{array}{c}\mathrm{Mg}^{2+} \\
\mathrm{mg} \mathrm{L}^{-1}\end{array}$ & $\begin{array}{c}\mathrm{Ca}^{2+} \\
\mathrm{mg} \mathrm{L}^{-1}\end{array}$ \\
\hline \multirow{6}{*}{ Corn Silage } & \multirow{2}{*}{$\begin{array}{l}\text { Neocallimastix } \\
\text { frontalis }\end{array}$} & Inactivated & $\mathrm{N} / \mathrm{A}$ & $0.87 \pm 0.18$ & $2.14 \pm 0.13$ & $0.14 \pm 0.00$ & $0.17 \pm 0.00$ \\
\hline & & Active & $\mathrm{N} / \mathrm{A}$ & $0.80 \pm 0.08$ & $2.20 \pm 0.08$ & $0.17 \pm 0.02$ & $0.23 \pm 0.02$ \\
\hline & \multirow{2}{*}{$\begin{array}{l}\text { Anaeromyces } \\
\text { mucronatus }\end{array}$} & Inactivated & N/A & $0.79 \pm 0.08$ & $2.19 \pm 0.17$ & $0.15 \pm 0.02$ & $0.21 \pm 0.03$ \\
\hline & & Active & $\mathrm{N} / \mathrm{A}$ & $0.75 \pm 0.02$ & $2.07 \pm 0.02$ & $0.14 \pm 0.01$ & $0.20 \pm 0.02$ \\
\hline & \multirow{2}{*}{ Piromyces rhizinflata } & Inactivated & N/A & $0.72 \pm 0.03$ & $2.00 \pm 0.11$ & $0.12 \pm 0.00$ & $0.18 \pm 0.01$ \\
\hline & & Active & $\mathrm{N} / \mathrm{A}$ & $0.72 \pm 0.03$ & $2.08 \pm 0.09$ & $0.13 \pm 0.01$ & $0.20 \pm 0.01$ \\
\hline \multirow{6}{*}{$\begin{array}{l}\text { Phragmites } \\
\text { australis }\end{array}$} & \multirow{2}{*}{$\begin{array}{l}\text { Neocallimastix } \\
\text { frontalis }\end{array}$} & Inactivated & $78.45 \pm 5.62$ & $0.57 \pm 0.03$ & $1.63 \pm 0.02$ & $0.12 \pm 0.01$ & $0.19 \pm 0.02$ \\
\hline & & Active & $14.71 \pm 0.09$ & $0.61 \pm 0.02$ & $1.64 \pm 0.03$ & $0.12 \pm 0.00$ & $0.22 \pm 0.01$ \\
\hline & \multirow{2}{*}{$\begin{array}{l}\text { Anaeromyces } \\
\text { mucronatus }\end{array}$} & Inactivated & $41.10 \pm 0.42$ & $0.53 \pm 0.04$ & $1.59 \pm 0.02$ & $0.10 \pm 0.00$ & $0.21 \pm 0.00$ \\
\hline & & Active & $37.66 \pm 14.56$ & $0.64 \pm 0.02$ & $1.58 \pm 0.03$ & $0.08 \pm 0.00$ & $0.16 \pm 0.01$ \\
\hline & \multirow{2}{*}{ Piromyces rhizinflata } & Inactivated & $44.11 \pm 2.05$ & $0.59 \pm 0.03$ & $1.63 \pm 0.07$ & $0.08 \pm 0.00$ & $0.16 \pm 0.00$ \\
\hline & & Active & $25.81 \pm 0.36$ & $0.58 \pm 0.03$ & $1.58 \pm 0.08$ & $0.10 \pm 0.00$ & $0.21 \pm 0.01$ \\
\hline
\end{tabular}

Anaerobic fungi are known for having a close symbiotic activity and interspecies $\mathrm{H}_{2}$ transfer with other microbes in the rumen $[37,38]$. The absence of these relationships, or the lack of time for such relationships to develop using the experimental design of this study, may also account for the poor hydrolytic activity observed. Coculturing AF with other rumen hydrolytic bacteria, such as Fibrobacter succinogenes, could be a potential approach to take in the future to increase viability [39]. Joblin et al. [40] inoculated F. succinogenes together with methanogenic cocultures of Caecomyces/M. smithii grown on rye grass. They found that there was an increase in stem degradation and attributed this to complementary fibrolytic activities between the two species. By comparison, our study utilized only AF to help degrade the substrate. The heat sterilization used to eliminate background microflora from anaerobic digestate may have limited potential for symbiotic relationships to develop between AF and bacteria. Conversely, antibiosis has been reported between ruminal bacteria and AF in laboratory studies [41], which highlights our current poor understanding of AF ecology.

Ylldırım et al. [42] recently reported up to a $60 \%$ increase in biogas yield from animal manures bioaugmented anaerobic fungi. In that study, the authors used an undefined mixture of AF isolated from a cow's rumen, resulting in an AF community composed of $>6$ groups (including Anaeromyces spp., Neocallimastix spp., and Piromyces spp. used in our study) [43]. It is possible that the mixed AF culture approach is a better strategy for ensuring AF activity and survival when used in bioaugmentation compared to single species inoculations, as we have described here. The benefit of a mixed AF culture could be due simply to higher diversity increasing the chances for survival under artificial conditions, and/or could be due to interactions between the different community members. The combination of our results and those by [42] strongly suggest that successful outcomes from the addition of $\mathrm{AF}$ to hydrolysis and/or anaerobic digestion may require use of mixed complex communities.

\section{Conclusions}

Hydrolysis of corn silage and common reed were not improved by bioaugmentation with three different species of $A F$, as evidenced by a lack of significant $\mathrm{H}_{2}$ production or substrate degradation compared to controls. The most likely explanation for these results is that AF had low activity and/or survival in the anaerobic fermentation systems used in this study. More research is required to better understand survival of $\mathrm{AF}$ in anaerobic digestion processes to determine the feasibility of exploiting these organisms for lignocellulosic degradation.

Author Contributions: Conceptualization, B.R. and B.H.G.; methodology, B.R., V.N.N. and J.Y.; software, B.R. and B.H.G.; validation, B.R., V.N.N. and B.H.G.; formal analysis, B.R.; investigation, B.R. and V.N.N.; resources, X.H., J.Y., T.A.M. and B.H.G.; data curation, B.R. and V.N.N.; writingoriginal draft preparation, B.R.; writing—review and editing, V.N.N., C.V., X.H., J.Y., T.A.M., H.L. and B.H.G.; visualization, B.R. and B.H.G.; supervision, X.H., H.L. and B.H.G.; project administration, 
B.H.G.; funding acquisition, X.H., T.A.M. and B.H.G. All authors have read and agreed to the published version of the manuscript.

Funding: This work was supported by the Natural Resources Canada Program of Energy Research and Development (grant number Inc001), Agriculture and Agri-Food Canada (grant number T.2002.36), and the Natural Sciences and Engineering Research Council of Canada (grant number 400806).

Institutional Review Board Statement: Not applicable.

Informed Consent Statement: Not applicable.

Data Availability Statement: Not applicable.

Acknowledgments: The authors wish to thank Kurtis Baute, Kimberley Van Overloop, Greg Travis, Douglas Marchbank, Stephanie Montienth, Winnie Lao, and Raene Barber for their technical assistance on this research project.

Conflicts of Interest: The authors declare no conflict of interest.

\section{References}

1. $\quad$ EBA. EBA Stastical Report 2020; European Biogas Association: Brussels, Belgium, 2020.

2. Hutňan, M. Maize Silage as Substrate for Biogas Production. In Advances in Silage Production and Utilization; Silva, T.D., Ed.; IntechOpen: Rijeka, Croatia, 2016.

3. Lask, J.; Guajardo, A.M.; Weik, J.; von Cossel, M.; Lewandowski, I.; Wagner, M. Comparative environmental and economic life cycle assessment of biogas production from perennial wild plant mixtures and maize (Zea mays L.) in southwest Germany. GCB Bioenergy 2020, 12, 571-585. [CrossRef]

4. $\quad$ Baute, K.; Van Eerd, L.L.; Robinson, D.E.; Sikkema, P.H.; Mushtaq, M.; Gilroyed, B.H. Comparing the Biomass Yield and Biogas Potential of Phragmites australis with Miscanthus x giganteus and Panicum virgatum Grown in Canada. Energies 2018, 11, 2198. [CrossRef]

5. Vaičekonytė, R.; Kiviat, E.; Nsenga, F.; Ostfeld, A. An exploration of common reed (Phragmites australis) bioenergy potential in North America. Mires Peat 2014, 13, 1-9.

6. Akula, V.R. Wetland Biomass-Suitable for Biogas Production? Master's Thesis, Halmsted University, Halmstad, Sweden, 2013.

7. Wang, C.; Kong, Y.; Hu, R.; Zhou, G. Miscanthus: A fast-growing crop for environmental remediation and biofuel production. GCB Bioenergy 2021, 13, 58-69. [CrossRef]

8. e Silva, C.F.L.; Schirmer, M.A.; Maeda, R.N.; Barcelos, C.A.; Pereira, N. Potential of giant reed (Arundo donax L.) for second generation ethanol production. Electron. J. Biotechnol. 2015, 18, 10-15. [CrossRef]

9. Bayané, A.; Guiot, S. Animal digestive strategies versus anaerobic digestion bioprocesses for biogas production from lignocellulosic biomass. Rev. Environ. Sci. Bio/Technol. 2011, 10, 43-62. [CrossRef]

10. Dollhofer, V.; Podmirseg, S.M.; Callaghan, T.M.; Griffith, G.W.; Fliegerová, K. Anaerobic Fungi and Their Potential for Biogas Production. Adv. Biochem. Eng. Biotechnol. 2015, 151, 41-61.

11. Wei, Y.Q.; Yang, H.J.; Luan, Y.; Long, R.J.; Wu, Y.J.; Wang, Z.Y. Isolation, identification and fibrolytic characteristics of rumen fungi grown with indigenous methanogen from yaks (Bos grunniens) grazing on the Qinghai-Tibetan Plateau. J. Appl. Microbiol. 2016, 120, 571-587. [CrossRef]

12. Dollhofer, V.; Podmirseg, S.M.; Callaghan, T.M.; Griffith, G.W.; Fliegerová, K. Anaerobic Fungi and Their Potential for Biogas Production. In Biogas Science and Technology; Guebitz, G.M., Bauer, A., Bochmann, G., Gronauer, A., Weiss, S., Eds.; Springer International Publishing: Cham, Switzerland, 2015; pp. 41-61.

13. Janusz, G.; Pawlik, A.; Sulej, J.; Swiderska-Burek, U.; Jarosz-Wilkolazka, A.; Paszczynski, A. Lignin degradation: Microorganisms, enzymes involved, genomes analysis and evolution. FEMS Microbiol. Rev. 2017, 41, 941-962. [CrossRef]

14. Vogel, T.M. Bioaugmentation as a soil bioremediation approach. Curr. Opin. Biotechnol. 1996, 7, 311-316. [CrossRef]

15. Miah, M.S.; Tada, C.; Sawayama, S. Enhancement of Biogas Production from Sewage Sludge with the Addition of Geobacillus sp. Strain AT1 Culture. Jpn. J. Water Treat. Biol. 2004, 40, 97-104. [CrossRef]

16. Müller, H.; Trösch, W. Screening of white-rot fungi for biological pretreatment of wheat straw for biogas production. Appl. Microbiol. Biotechnol. 1986, 24, 180-185. [CrossRef]

17. Saye, L.M.; Navaratna, T.A.; Chong, J.P.; O'Malley, M.A.; Theodorou, M.K.; Reilly, M. The anaerobic fungi: Challenges and opportunities for industrial lignocellulosic biofuel production. Microorganisms 2021, 9, 694. [CrossRef] [PubMed]

18. Nkemka, V.N.; Gilroyed, B.H.; Yanke, J.; Gruninger, R.; Vedres, D.; McAllister, T.; Hao, X. Bioaugmentation with an anaerobic fungus in a two-stage process for biohydrogen and biogas production using corn silage and cattail. Bioresour. Technol. 2015, 185, 79-88. [CrossRef] [PubMed]

19. Liang, J.; Zhang, H.; Zhang, P.; Zhang, G.; Cai, Y.; Wang, Q.; Zhou, Z.; Ding, Y.; Zubair, M. Effect of substrate load on anaerobic fermentation of rice straw with rumen liquid as inoculum: Hydrolysis and acidogenesis efficiency, enzymatic activities and rumen bacterial community structure. Waste Manag. 2021, 124, 235-243. [CrossRef] [PubMed] 
20. Dollhofer, V.; Callaghan, T.M.; Griffith, G.W.; Lebuhn, M.; Bauer, J. Presence and transcriptional activity of anaerobic fungi in agricultural biogas plants. Bioresour. Technol. 2017, 235, 131-139. [CrossRef]

21. Lowe, S.E.; Theodorou, M.K.; Trinci, A.P.J.; Hespell, R.B. Growth of anaerobic rumen fungi on defined and semi-difined media lacking rumen fluid. J. Gen. Microbiol. 1985, 131, 2225-2229.

22. Hungate, R.E. The anaerobic mesophilic cellulolytic bacteria. Bacteriol. Rev. 1950, 14, 1-49. [CrossRef]

23. Nkemka, V.N.; Murto, M. Two-stage anaerobic dry digestion of blue mussel and reed. Renew. Energy 2013, 50, 359-364. [CrossRef]

24. Gilroyed, B.H.; Li, C.; Hao, X.; Chu, A.; McAllister, T.A. Biohydrogen production from specified risk materials co-digested with cattle manure. Int. J. Hydrogen Energy 2010, 35, 1099-1105. [CrossRef]

25. APHA. Standard Methods for the Examination of Water and Wastewater; APHA-AWWA-WEF: Washington, DC, USA, 2005.

26. Gilroyed, B.H.; Li, C.; Reuter, T.; Beauchemin, K.A.; Hao, X.; McAllister, T. Influence of distiller's grains and condensed tannins in the diet of feedlot cattle on biohydrogen production from cattle manure. Int. J. Hydrogen Energy 2015, 40, 6050-6058. [CrossRef]

27. Gilroyed, B.H.; Reuter, T.; Chu, A.; Hao, X.; Xu, W.; McAllister, T.A. Anaerobic digestion of specified risk materials with cattle manure for biogas production. Bioresour. Technol. 2010, 101, 5780-5785. [CrossRef] [PubMed]

28. Van Soest, P.J.; Robertson, J.B.; Lewis, B.A. Methods for dietary fiber, neutral detergent fiber, and nonstarch polysaccharides in relation to animal nutrition. J. Dairy Sci. 1991, 74, 3583-3597. [CrossRef]

29. Mertens, D.R.; Allen, M.; Carmany, J.; Clegg, J.; Davidowicz, A.; Drouches, M.; Frank, K.; Gambin, D.; Garkie, M.; Gildemeister, B.; et al. Gravimetric determination of amylase-treated neutral detergent fiber in feeds with refluxing in beakers or crucibles: Collaborative study. J. AOAC Int. 2002, 85, 1217-1240.

30. Rabii, A.; Aldin, S.; Dahman, Y.; Elbeshbishy, E. A review on anaerobic co-digestion with a focus on the microbial populations and the effect of multi-stage digester configuration. Energies 2019, 12, 1106. [CrossRef]

31. Gruninger, R.J.; Puniya, A.K.; Callaghan, T.M.; Edwards, J.E.; Youssef, N.; Dagar, S.S.; Fliegerova, K.; Griffith, G.W.; Forster, R.; Tsang, A.; et al. Anaerobic fungi (phylum Neocallimastigomycota): Advances in understanding their taxonomy, life cycle, ecology, role and biotechnological potential. Fems. Microbiol. Ecol. 2014, 90, 1-17. [CrossRef]

32. Borreani, G.I.; Tabacco, E.R.; Schmidt, R.J.; Holmes, B.J.; Muck, R.E. Silage review: Factors affecting dry matter and quality losses in silages. J. Dairy Sci. 2018, 101, 3952-3979. [CrossRef]

33. Uwineza, C.; Mahboubi, A.; Atmowidjojo, A.C.; Ramadhani, A.N.; Wainaina, S.; Millati, R.; Wikandari, R.; Niklasson, C.; Taherzadeh, M.J. Cultivation of edible filamentous fungus Aspergillus oryzae on volatile fatty acids derived from anaerobic digestion of food waste and cow manure. Bioresour. Technol. 2021, 337, 125410. [CrossRef]

34. Chen, Y.; Cheng, J.J.; Creamer, K.S. Inhibition of anaerobic digestion process: A review. Bioresour. Technol. 2008, 99, 4044-4064. [CrossRef]

35. Romero-Güiza, M.S.; Mata-Alvarez, J.; Chimenos, J.M.; Astals, S. The effect of magnesium as activator and inhibitor of anaerobic digestion. Waste Manag. 2016, 56, 137-142. [CrossRef]

36. Veluchamy, C.; Kalamdhad, A.S. Influence of pretreatment techniques on anaerobic digestion of pulp and paper mill sludge: A review. Bioresour. Technol. 2017, 245, 1206-1219. [CrossRef] [PubMed]

37. Ivarsson, M.; Schnürer, A.; Bengtson, S.; Neubeck, A. Anaerobic fungi: A potential source of biological H2 in the oceanic crust. Front. Microbiol. 2016, 7, 674. [CrossRef] [PubMed]

38. Hess, M.; Paul, S.S.; Puniya, A.K.; van der Giezen, M.; Shaw, C.; Edwards, J.E.; Fliegerová, K. Anaerobic Fungi: Past, Present, and Future. Front. Microbiol. 2020, 11, 584893. [CrossRef]

39. Kobayashi, Y.; Shinkai, T.; Koike, S. Ecological and physiological characterization shows that Fibrobacter succinogenes is important in rumen fiber digestion. Folia Microbiol. 2008, 53, 195-200. [CrossRef] [PubMed]

40. Joblin, K.N.; Matsui, H.; Naylor, G.E.; Ushida, K. Degradation of Fresh Ryegrass by Methanogenic Co-Cultures of Ruminal Fungi Grown in the Presence or Absence of Fibrobacter succinogenes. Curr. Microbiol. 2002, 45, 46-53. [CrossRef]

41. Dehority, B.A.; Tirabasso, P.A. Antibiosis between Ruminal Bacteria and Ruminal Fungi. Appl. Environ. Microb. 2000, 66, 2921-2927. [CrossRef]

42. Yıldırım, E.; Ince, O.; Aydin, S.; Ince, B. Improvement of biogas potential of anaerobic digesters using rumen fungi. Renew. Energy 2017, 109, 346-353. [CrossRef]

43. Aydin, S.; Yıldırım, E.; Ince, O.; Ince, B. Rumen anaerobic fungi create new opportunities for enhanced methane production from microalgae biomass. Algal Res. 2017, 23, 150-160. [CrossRef] 